190

Received: September 10, 2014

Accepted: November 19, 2014
Macedonian Journal of Animal Science, Vol. 4, No. 2, pp. 75-78 (2014)

In print: ISSN $1857-6907$

On line: ISSN $1857-7709$

UDC: 637.523 .055

Original scientific paper

\title{
INFLUENCE OF THE LACTATE ON THE MICROBIOLOGICAL AND SENSORY PROPERTIES IN SEMIDURABLE SAUSAGES
}

\author{
Aco Kuzelov ${ }^{1}$, Nako Taškov ${ }^{2}$, Dušica Saneva ${ }^{2}$, Oksana Savinok ${ }^{3}$ \\ ${ }^{1}$ Faculty of Agriculture, University ,, Goce Delčev“, Štip, Republic of Macedonia \\ ${ }^{2}$ Faculty of Tourism and Business Logistics, University „, Goce Delčev“, Štip, Republic of Macedonia \\ ${ }^{3}$ National Academy of Food Technology, Odessa, Ukraine \\ aco.kuzelov@ugd.edu.mk
}

\begin{abstract}
This paper presents the influence of the lactate on the microbiological and sensory properties of semi-durable sausage. The addition of lactate a favorably affect the microbiological picture of the total number of bacteria and the sensory properties of semi-durable sausage. The addition of lactate preserved the sensory properties of the treated samples with lactate and their extended period of use.
\end{abstract}

Key words: lactate; microbiological image; sensory properties; semi-durable sausage

\section{ВЛИЈАНИЕ НА ЛАКТАТИТЕ ВРЗ МИКРОБИОЛОШКИТЕ И СЕНЗОРНИТЕ СВОЈСТВА НА ПОЛУТРАЈНИ КОЛБАСИ}

\begin{abstract}
Во овој труд е испитувано влијанието на лактатите врз микробиолошката слика и сензорните особини на полутраен народен колбас. Додавањето на лактатите поволно влијае на микробиолошката слика во однос на вкупниот број бактерии и на сензорните особини на народниот колбас. Додатокот на лактат ги зачувал сензорните особини на третираните примероци и им го продолжил рокот на употреба.
\end{abstract}

Клучни зборови: лактат; микробиолошка слика; сензорни карактеристики; полутраен колбас

\section{INTRODUCTION}

Extending the durability of meat products propound a request before producers and processors to introduce new technological barriers for reproduction of the microorganisms. The challenge of achieving security and control product is tied to the manner and conditions of manufacture and the storage and distribution of products in order to obtain a quality and safe product. Meat products are perishable products and therefore are looking for ways to maintain and extend its. For this purpose it is used, citrate, acetate, lactate individually or in combination. The addition of lactate to the product in the processing effectively retained in the development of microorganisms whit acidic environment. Rapid reduction of the $\mathrm{pH}$ leads to termination of the life activities of microorganisms penetrate lactate addition in microbial cells and stop processes sharing them. As a result, morphological changes occur (Dragoev, 2004; Paul et al., 2007). Besides bacteriological effect and the lactate contribute to better profitability arising from the impact of reducing Kahlo production during thermal processing and storage of meat products. Moreover, lactate positively affect the reduction of color, texture, flavor and aroma products (Bloukas et al., 1997). The addition of 1 to $2 \%$ sodium lactate in vacuum packaged fresh pork sausages were continued for 14 days duration (Brewer et al, 1993). The impact of potassium lactate and type of fresh pork sausage fresh light and darkness in the area studied by Schmidt et al. (2009). They examined the influence of potassium and sodium lactate in different combinations on minced beef meat packaged in modified atmosphere and stored at $2^{\circ} \mathrm{C}$ and $8^{\circ} \mathrm{C}$. Determined that the addition of lactate in all combinations at improving the microbiological and sensory characteristics in the treated samples compared with untreated. Ramanathan and 
Mancini (2008) confirmed the positive effect of lactate on the color stability of meat and meat products. Because there are not or very little information on the impact of lactate on the sausages, we decided to examine the impact of lactate on microbiological image (total number of bacteria) and sensory properties of the sausages.

\section{MATERIAL AND METHOD}

As material for examination we have used the type: semi-durable sausage "National". Sausage was produced by all veterinary sanitary regulations which apply to R. Macedonia (Gazette of RM, No. $63 / 2013$ ) is classified as a rough-hewn boiled semi-durable sausage. Sausage was produced from fresh pork and beef, dietary additives and spices. Two samples were prepared, one standard - without lactate, and other with lactate. Lactate was added to the product during the grinding in the amount of $2 \%$ compared to the weight of the product. After filling up and hanging the sausage was measured and it was heated by the following formula.

Thermal processing: $35 \mathrm{~min}$ of drying at $62^{\circ} \mathrm{C}, 20 \mathrm{~min}$ of smoking at $62^{\circ} \mathrm{C}, 35 \mathrm{~min}$ of digestion at $78^{\circ} \mathrm{C}$. After heat treatment a vacuum type machine Vebomatik was using. After vacuum sausage is stored at $+4^{\circ} \mathrm{C}$ and $6^{\circ} \mathrm{C}$. Of these samples is examination microbiological (total number of bacteria) and sensory properties.

\section{Microbiological examination}

For bacteriological examination material was taken from each sample - $20 \mathrm{~g}$ of material which before planting is homogenized with $180 \mathrm{ml}$ sterile distilled water from which is made other dilutions. The number of bacteria is in $\log$.CFU/g. It was examined the total number of bacteria in the method ISO $4833 / 2008$. The test was performed immediately after charging to thermal treatment after the first heat treatment day, 15, 45, 55 and 65 days from the manufacture .

\section{Sensory examination}

Sensory examination are made using a quantitative descriptive test of numerical descriptive scale shown in Table 1 on a scale of 1 to 5. Assessed following sensory attributes: external appearance, color, smell, taste, consistency. The evaluation was performed by a 5 experienced spe- cialists. Sensory examination was performed 1, 15, 45,55 and 65 days production.

Table 1

Total number of bacteria (log / CFU/g) test specimens stored at temperature of $4^{\circ} \mathrm{C}$ and $6^{\circ} \mathrm{C}$

\begin{tabular}{lcc|cc}
\hline \hline & \multicolumn{3}{c}{ Untreated samples } & Treated samples \\
Days & $4^{\circ} \mathrm{C}$ & $6^{\circ} \mathrm{C}$ & $4^{\circ} \mathrm{C}$ & $6^{\circ} \mathrm{C}$ \\
\hline Immediately after charging & 5.42 & 5.75 & 4.20 & 4.50 \\
1 day of production & 5.50 & 5.58 & 3.45 & 3.90 \\
15 days of production & 5.58 & 5.82 & 3.90 & 3.70 \\
45 days of production & 5.65 & 5.85 & 4.20 & 4.85 \\
55 days of production & 5.78 & 6.58 & 4.55 & 5.12 \\
65 days of production & 6.80 & 7.20 & 4.98 & 5.42 \\
\hline \hline
\end{tabular}

\section{Statistical processing}

The obtained results have processed mathematical statistics using Microsoft Excel 2003 and his standard accessory Data Analysis Tool Pak.

\section{RESULTS AND DISCUSSION}

The table shows that untreated control samples stored at temperature $4^{\circ} \mathrm{C}$ and $6^{\circ} \mathrm{C}$ had the highest values of the total number of bacteria. After filling immediately the number of bacteria determined in untreated samples stored at $4{ }^{\circ} \mathrm{C}$ and $6^{\circ} \mathrm{C}$ was 5.42 and $5.75 \mathrm{log} / \mathrm{CFU} / \mathrm{g}$. A treated with 4.20 and $4.50 \log / \mathrm{CFU} / \mathrm{g}$. The 1, 15, 45 and 55 and 65 days production total number of bacteria in untreated samples kept at a temperature of $4{ }^{\circ} \mathrm{C}$ and $6^{\circ} \mathrm{C}$ increases by 5.50 and $5.58 \log / \mathrm{CFU} / \mathrm{g}$. to 6.80 and $7.20 \log / \mathrm{CFU} / \mathrm{g}$ the $65^{\text {th }}$ day of storage. Treated samples stored at temperature $4{ }^{\circ} \mathrm{C}$ and $6^{\circ} \mathrm{C}$ had a total number of bacteria 4.20 and $4.0 \mathrm{log} /$ $\mathrm{CFU} / \mathrm{g}$ immediately after charging the 65 days of storage had a total number of bacteria 4.98 and $5.42 \mathrm{log} / \mathrm{CFU} / \mathrm{g}$. The differences between the values obtained at 1,15 and 45 days production in sausages stored at $4^{\circ} \mathrm{C}$ and $6^{\circ} \mathrm{C}$ between the control sample and treated samples are statistically significant $(\mathrm{p}>0.05)$.

Crossing the limits at $7.0 \mathrm{log} / \mathrm{CFU} / \mathrm{g}$ occurs in untreated samples kept at a temperature of $6^{\circ} \mathrm{C}$ to 65 days. The table shows that untreated control samples stored at temperature $4^{\circ} \mathrm{C}$ and $6^{\circ} \mathrm{C}$ had the 
highest values of the total number of bacteria and compared values of the treated samples is probably due to the application of lactate in their production.

\section{Sensory analysis}

Tables 2 and 3 show at the first day to the 45 days haven't significant deviations of sensory characteristics in both groups studied sausages kept at a temperature of $4^{\circ} \mathrm{C}$ and $6^{\circ} \mathrm{C}$. Significant differences were observed after 55 days of storage with the greatest deviation in samples without addition of lactate. Samples with added lactate is a well rated in all evaluated sensory properties of the samples without addition of lactate which confirms the contention of some authors that lactate positively affect the reduction of color, texture, flavor and fragrance products (Bloukas et al. 1997).

Table 2

Sensory analysis of tested samples kept at a temperature of $4^{\circ} \mathrm{C}$

\begin{tabular}{|c|c|c|c|c|c|c|c|c|c|c|}
\hline \multirow{3}{*}{$\begin{array}{l}\text { Sensory } \\
\text { properties }\end{array}$} & \multicolumn{10}{|c|}{ D a y s } \\
\hline & \multicolumn{5}{|c|}{ Untreated samples } & \multicolumn{5}{|c|}{ Treated sample } \\
\hline & 1 & 15 & 45 & 55 & 65 & 1 & 15 & 45 & 55 & 65 \\
\hline Color section & $8,20 \pm 0,10$ & $7,40 \pm 0,12$ & $6,70 \pm 0,20$ & $5,45 \pm 0,20$ & $4,48 \pm 0,20$ & $8,78 \pm 0,05$ & $8,58 \pm 020$ & $7,90 \pm 0,25$ & $6,78 \pm 0,18$ & $5,80 \pm 0,28$ \\
\hline Smell & $8,12 \pm 0,25$ & $7,28 \pm 0,12$ & $6,40 \pm 0,18$ & $5,28 \pm 0,52$ & $4,42 \pm 0,28$ & $8,55 \pm 0,48$ & $8,42 \pm 0,18$ & $7,58 \pm 0,22$ & $6,55 \pm 0,12$ & $5,72 \pm 0,10$ \\
\hline Taste & $8,40 \pm 0,12$ & $7,20 \pm 0,18$ & $6,20 \pm 0,42$ & $5,20 \pm 0,48$ & $4,28 \pm 0,40$ & $8,58 \pm 0,12$ & $8,72 \pm 0,42$ & $7,58 \pm 0,48$ & $8,88 \pm 0,20$ & $5,55 \pm 0,40$ \\
\hline Consistency & $8,72 \pm 0,28$ & $7,42 \pm 0,42$ & $6,20 \pm 0,10$ & $5,25 \pm 0,20$ & $4,28 \pm 0,50$ & $8,88 \pm 0,20$ & $8,78 \pm 0,45$ & $7,58 \pm 0,72$ & $6,58 \pm 0,52$ & $5,70 \pm 0,20$ \\
\hline
\end{tabular}

Table 3

Sensory analysis of tested samples kept at a temperature of $6^{\circ} \mathrm{C}$

\begin{tabular}{|c|c|c|c|c|c|c|c|c|c|c|}
\hline \multirow{3}{*}{$\begin{array}{l}\text { Sensory } \\
\text { properties }\end{array}$} & \multicolumn{10}{|c|}{ D a y s } \\
\hline & \multicolumn{5}{|c|}{ Untreated samples } & \multicolumn{5}{|c|}{ Treated sample } \\
\hline & 1 & 15 & 45 & 55 & 65 & 1 & 15 & 45 & 55 & 65 \\
\hline Color section & $7,80 \pm 0,20$ & $7,20 \pm 0,18$ & $6,50 \pm 0,28$ & $5,10 \pm 0,10$ & $4,20 \pm 0,42$ & $8,70 \pm 0,10$ & $8,52 \pm 025$ & $7,70 \pm 0,28$ & $6,80 \pm 0,10$ & $5,50 \pm 0,58$ \\
\hline Smell & $8,05 \pm 0,25$ & $7,10 \pm 0,18$ & $6,28 \pm 0,20$ & $5,18 \pm 0,28$ & $4,58 \pm 0,72$ & $8,40 \pm 0,48$ & $8,42 \pm 0,18$ & $7,58 \pm 0,22$ & $6,48 \pm 0,15$ & $5,55 \pm 0,52$ \\
\hline Taste & $8,18 \pm 0,22$ & $7,42 \pm 0,42$ & $6,12 \pm 0,52$ & $5,05 \pm 0,12$ & $4,72 \pm 0,12$ & $8,50 \pm 0,42$ & $8,72 \pm 0,42$ & $7,58 \pm 0,48$ & $6,48 \pm 0,22$ & $5,28 \pm 0,72$ \\
\hline Consistency & $8,25 \pm 0,28$ & $7,22 \pm 0,42$ & $6,20 \pm 0,10$ & $4,82 \pm 0,18$ & $4,20 \pm 0,52$ & $8,80 \pm 0,22$ & $8,42 \pm 0,40$ & $7,58 \pm 0,22$ & $6,85 \pm 0,78$ & $5,18 \pm 0,12$ \\
\hline
\end{tabular}

The color samples without addition of lactate had little stability after and got low grades in samples kept at a temperature of $4^{\circ} \mathrm{C}$ and $6^{\circ} \mathrm{C}$ compared to samples with addition of lactate kept the same temperatures probably due to the action of lactate which positively affect the color of meat and meat products (Püssa et al., 2009). On days 55 to 65 samples without addition of lactate at all tested sensory properties received low marks as a result of declining quality of sensory attributes with the greatest departure in samples not containing lactate held at a temperature of $6^{\circ} \mathrm{C}$.

\section{CONCLUSION}

With the addition of lactate production in the semi-durable sausage is visible improvement the microbiological and sensory evaluation. In sausages treated with lactate interesting is the appearance of reducing the number of microorganisms and better grades of sensory properties held temperature and $4^{\circ} \mathrm{C}$ except that a slightly higher total number of bacteria after weak sensory grades there in treated sausages with lactate kept at a temperature of $6^{\circ} \mathrm{C}$. 
The obtained results show a positive effect on lactate coupled with vacuuming sausages on the microbiological and sensory characteristics picture, and therefore an extension the durability of sausages. The addition of lactate production during the popular sausage is desired and desirable as a positive influence on the product that is continuing durability of the products in it without breaking the sensory properties of the sausages.

\section{REFERENCE}

[1] Dragoev, S.: Development of technology in the industry for temperature had on good sensory characteristics of meat cuts that meat and fish, Academic Edition, UFT Plovdiv, 259-263 (2004).

[2] Paul, S. K., Samanta, G., Halder, G., Biswas, P.: Effect of a combination of organic acid salts as antibiotic replacer on the performance and gut health of broiler chickens,
Livestock Research for rural development, 19, 1-8 (2007).

[3] Bloukas, J. G., Paneras, E. D., Fournitzis, G. C.: Sodium lactate and protective culture effects on quality characteristics and shelf-life of low-fat Frankfurters produced with olive oil. Meat Sci. 45, 223-238 (1997).

[4] Brewer, M. S., McKeith, F. K., Sprouls, G.: Sodiuum lactate effect on shelf-life, sensory and physical characteristics of vacuum package freshpork sausage, J. Muscle Foods, 4, pp.179-192 (1993).

[5] Šmidt G., Kovačić, M., Gregurić, I., Bertinovec, I.: Učinak kalievog i natrievog laktata na održlivost svežeg junećeg mlevenog mesa pri različitim uvjetima skladištenja, Meso 1, 22-31 (2009).

[6] Püssa, T., Raudsepp, P., Toomik, P., Pällin, R., Mäeorg, U., Kuusik, S., Soidla, R., Rei, M.: A study of oxidation products of free polyunsaturated fatty acids in mechanically deboned meat, J. Food Composition and Analysis 22, 307-314 (2009).

[7] Ramanathan, R., Mancini, R. A.: Sodium lactate influenfces myoglobin redox stability in vitro. Meat Sci. 78, 529-532 (2008). 